\title{
How about the dikes? Managed realignment in progress at the Hedwige- Prosperpolder
}

\author{
Kim van den Hoven ${ }^{1, a}$, Carolien Kroeze ${ }^{1}$ and Jantsje M. van Loon-Steensma ${ }^{1}$ \\ ${ }^{1}$ Wageningen University, Water Systems and Global Change group, Droevendaalsesteeg 3, 6708 PB Wageningen, The Netherlands
}

\begin{abstract}
Managed realignment is the landward relocation of a primary flood defence line. Because of this relocation, former land re-inundates, intertidal habitats can restore and new foreshores can develop adjacent to relocated dikes. Therefore, managed realignment can be considered a promising climate change adaptation measure that enables naturebased flood protection. This paper describes the Hedwige-Prosperpolder realignment preparations and aims to contribute to increased nature-based flood protection in future realignment projects. The Hedwige-Prosperpolder is located along the Scheldt estuary on the border of the Netherlands and Belgium. The return of tidal flow into the polder will be facilitated by dike adjustments and manmade creeks. We argue that due to climate change further research is needed on the potential of sustainable flood risk reduction by managed realignment. The Hedwige-Prosperpolder can serve as a Living Lab with many research possibilities during the realignment preparations and after the dikes will be breached. Sustainable managed realignment asks for research on the connection of the relocated dike to the intertidal habitat, both for nature restoration and for improved flood protection.
\end{abstract}

\section{Introduction to managed realignment}

In many deltaic regions the primary flood defence line is formed by dikes. These dikes keep water away from low-lying land and protect inhabitants from flooding. Dike construction also enabled polderisation, which is the deliberate reclamation of saltmarshes to provide (agricultural) land surface (e.g., van der Ham, 2009). Over the past decades, primary flood defences are being adjusted at some pilot locations to return water flow into parts of the low-lying land: the process of de-polderisation or managed realignment (e.g., Goeldner-Gianella, 2007; Esteves, 2014a). Managed realignment was recently identified as a promising sustainable climate change adaptation measure as it is driven by the combination of nature restoration and flood risk reduction (Temmerman et al., 2013).

Managed realignment is the landward relocation of the primary flood defence line (French, 2006). The new primary flood defence can be formed by the landscape topography or by a new, reinforced or existing landward defence structure. The presence of a new landward defence line, the relocated dike, allows for adjustments of the original primary flood defence. The original primary flood defence is generally lowered, breached or completely removed (Esteves, 2014b). These adjustments are usually managed but can also be induced by for instance a storm surge. The landward relocation of the primary flood defence line results in re-inundation of former land. Relocation thus creates accommodation space for sedimentation and a possibility for intertidal habitat restoration (Schuerch et al., 2018; Spencer et al., 2016). This restored intertidal habitat adjacent to the dike can contribute to flood protection through wave attenuation and wave impact reduction (e.g., Gedan et al., 2011; Reed et al., 2018; Shepard et al., 2011; Stark et al., 2016). The combination of flood protection by the relocated dikes and by the adjacent intertidal habitat suggests that managed realignment can be a nature-based flood protection where the dikes can connect with restored intertidal habitat (e.g., Bouma et al., 2014; van Loon-Steensma and Kok, 2016).

Managed realignment is being implemented globally, for instance in Bangladesh (e.g., van Staveren et al., 2017). However, most deliberate coastal and estuarine realignments seem to have been conducted in Europe, mainly in England, Germany and the Netherlands (e.g., OMReG by ABPmer: www.omreg.net; van den Hoven et al., in prep). Over 90 coastal and estuarine realignments have so far been realized in Belgium, Denmark, England, France, Germany, the Netherlands, Scotland and Spain (van den Hoven et al., in prep). Two thirds of these European projects are located in protected inlets, mainly in estuaries, and about one third is located at the exposed coast (van den Hoven et al., in prep). At the moment of writing, several realignment projects are under construction. For example, the Hedwige-Prosperpolder project that is initiated to restore intertidal nature in the Scheldt estuary as compensation for harbour extension. This paper describes the Hedwige-Prosperpolder realignment preparations and aims to contribute to 
increased nature-based flood protection in future realignment projects. To this end, we will first describe the Hedwige-Prosperpolder case. Next, we will compare it with some other cases of managed realignment. Finally, we will draw conclusions about how we can learn from the Hedwige-Prosperpolder case.

\section{Case study Hedwige-Prosperpolder}

The Hedwige-Prosperpolder managed realignment project is located on the border of the Netherlands and Belgium (Figure 1). The project area measures 465 ha and consists of the Dutch Hertogin Hedwige polder and part of the Belgium Hertog Prosper polder. The Hedwige polder is bordered by the Sieperda marsh (Figure 1). This marsh is a former polder that inundated after its summer dike breached during a storm in 1990 (Eertman, 2002). The Sieperda Marsh is separated from the large intertidal area 'Verdronken Land van Saefthinge' by a dam (Figure 1). Eventually, this 'Verdronken Land van Saefthinge' and the Sieperda marsh will be connected with the HedwigeProsper realignment area to create one large intertidal nature reserve.

The Hedwige-Prosperpolder project is along the brackish part of the Scheldt estuary. The tide in the Scheldt estuary is semi-diurnal. At the Hedwige-Prosperpolder, high-water levels are between 2.19 and 3.24 m NAP (neap and spring tide, respectively; NAP = Dutch ordnance level $\approx$ mean sea level). Low-water levels are between -1.88 (neap) and -2.49 (spring) m NAP. Average tidal range is $5.00 \mathrm{~m}$ (measured at the Dutch-Belgium border by the Mobility and Public Works department of the government of Flanders, available at waterinfo.be). Although the Hedwige-Prosperpolder dikes were constructed to resist extreme conditions such as in the estuary mouth near
Vlissingen, wave climate is mild in the Scheldt estuary on the border of Belgium and the Netherlands and waves mainly originate from ships sailing to and from the port of Antwerp.

At the time of writing, the Hedwige-Prosperpolder is still surrounded by the original primary dikes and by a new dike under construction. The original primary dikes are the Scheldt dike along the Scheldt estuary and the Sieperda dike between the Sieperda marsh and the Hedwige polder. There is also a dike between the Hedwige and the Prosper polder. Crest height of the Scheldt dike is between 8.70 and $9.22 \mathrm{~m} \mathrm{NAP}$ and crest height of the Sieperda dike is 9.61 m NAP (Bisschop et al., 2012). These two dikes are fronted by vegetated foreshores that consist mainly of reed vegetation (Reitsma and De Jong, 2018). The original dikes and foreshores will remain at least until the end of 2021. In the meantime, a new ring dike with a height of $10.2 \mathrm{~m}$ NAP is being constructed in the south, partly along the existing secondary dikes (Hubrechts and Defloor, 2018). The new dike will have a revetment of clay and

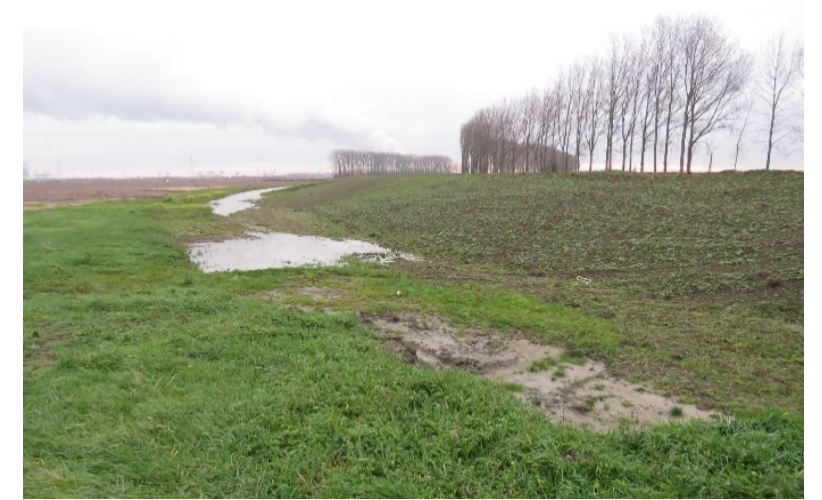

Figure 2 The new dike in the south of the Dutch Hedwige polder under construction. Photo by K. van den Hoven.
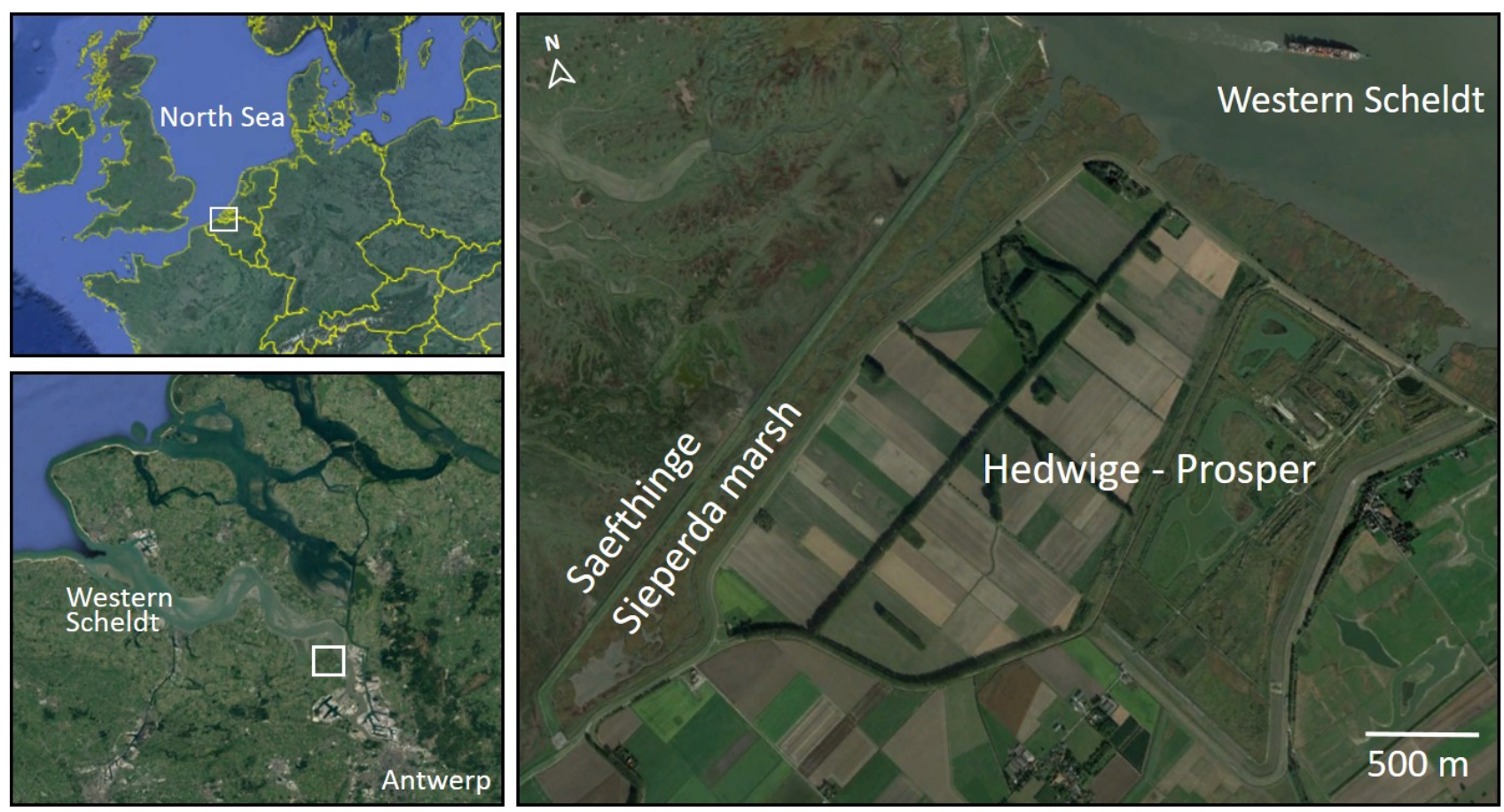

Figure 1 Hedwige-Prosperpolder location. Map data: Google Earth, Image Landsat/Copernicus, Data SIO, NOAA, U.S. Navy, NGA, GEBCO, imagery dates (clockwise from top left): US Depth of State Geographer, Google 2020; 10/05/2018; $14 / 13 / 2015$. 
open stone asphalt that allows vegetation growth (Hubrechts and Defloor, 2018). At the time of writing, the Belgium part of the new dike has been finalized while the Dutch part still has to be completed (Figure 2).

The Hedwige-Prosperpolder is mainly prepared for realignment by adjustments of the dikes. After completion of the new ring dike, the original primary dikes will be adjusted to return tidal flow into the former polders (personal communication with contractor). The original dikes will be lowered to polder elevation and several deliberate breaches are planned at historic tidal creek locations. Due to the presence of highly elevated foreshores in the Scheldt estuary, water flow through the deliberate breaches will have to be facilitated. Therefore, creeks are being excavated in these foreshores and inside the polder (Figure 3). These manmade creeks will also stimulate intertidal habitat restoration in the former polders. The polders itself are further prepared for tidal inundation by levelling elevation between the Dutch and Belgium part. Historically, the Dutch Hedwige polder was higher elevated then the Belgium Prosper polder. Other ongoing preparations in the polders are the removal of houses, trees and roads.

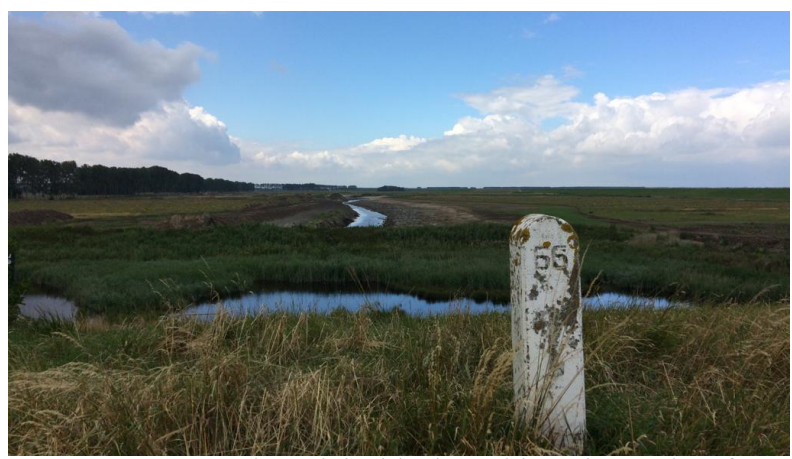

Figure 1 Excavated creek inside the polder. Photo taken from the Scheldt dike looking towards the polder. The Sieperda dike is visible in the far right. Photo by K. van den Hoven.

\section{Hedwige-Prosperpolder compared to other realignments}

Upon finalization, the Hedwige-Prosperpolder with its 465 ha of new intertidal habitat will be one of the largest managed realignment projects in Europe (OMReG by ABPmer: www.omreg.net; van den Hoven et al., in prep). The majority of European realignments are smaller than 150 ha (van den Hoven et al., in prep). Three projects larger than the Hedwige-Prosperpolder are located in Germany: the two coastal projects named Sundische Wiese (940 ha, De La Vega-Leinert and Stoll-Kleemann, 2015) and Geltinger Birk (1000 ha, Schernewski et al, 2018) and the Anklamer Stadtbruch project in a lagoon (1750 ha, Rupp-Armstrong and Nicholls, 2007). In comparison, the largest English projects are Medmerry on the Sussex coast (302 ha, e.g., Higuchi et al, 2014) and Alkborough in the Humber estuary (370 ha, Doody, 2008). The largest realignment known to the authors is the Saefthinge area in the Netherlands (3500 ha). This 'Verdronken Land van Saefthinge' can be seen as the oldest realignment site where the primary flood defence line shifted landwards from 1570 due to dike breaches and military purposes (Antea Group, 2013).

The dikes at Saefthinge can serve as an example for other dikes in managed realignment projects. Nowadays, the dikes around Saefthinge are all completely covered with a grass revetment as the presence of foreshores is taken into account for flood risk reduction (Waterschap Scheldestromen, personal communication). The green revetment allows for a better connection of the dikes with the vegetated foreshores. In comparison, the new dike at the Hedwige-Prosperpolder still has a partly open stone asphalt cover. This suggests that the presence of extensive foreshores, the polder area now and the future intertidal area, is not yet taken into account for flood risk reduction.

\section{Concluding remarks}

Dike construction and dike reinforcement has protected coastal and riverine communities from flooding for centuries. Due to climate change there is a search for new, sustainable solutions. A recent nature-based solution is the adjustment of dikes in managed realignment. Managed realignment provides both a combination of nature restoration and flood protection and a connection of dikes with vegetated foreshores. While foreshore development at realignment projects has been described extensively (e.g., Morris, 2013; Reed et al., 2018), not many studies exist on the flood protection aspect of managed realignment. We argue that further research on the potential of sustainable flood risk reduction under climate change by managed realignment is needed. The Hedwige-Prosperpolder realignment area can serve as a Living Lab with many research possibilities. The original primary dikes are available for field experiments with different maintenance regimes and the existing vegetated foreshores can be studied. Therefore, this unique Living Lab can provide more insight in the different aspects of managed realignment and increase our knowledge about nature-based flood protection.

\section{References}

1. Antea Group (2013). Ontwikkeling van een intergetijdengebied in Hedwige- en Prosperpolder: Definitief MER - tekstbundel. In opdracht van Provincie Zeeland.

2. Bisschop, C., C.E. Huisman, P.J.F. Beurskens , G. Karimlou, P. de Ruiter, G. van Doornik, K. van der Giessen and S. van Rooij (2012). Dijkring 32: Achtergrondrapport. Veiligheid Nederland in Kaart 2. Projectbureau VNK.

3. Bouma, T.J., J. van Belzen, T. Balke, Z. Zhu, L. Airoldi, A.J. Blight, A.J. Davies, C. Galvan, S.J. Hawkins, S.P.G. Hoggart, J.L. Lara, I.J. Losada, M. Maza, B. Barbara Ondiviela, M.W. Skov, E.M. Strain, R.C. Thompson, S. Yang, B. Zanuttigh, L. Zhang and P.M.J. Herman (2014). Identifying knowledge gaps hampering application of intertidal habitats in coastal protection: Opportunities \& steps to take. Coastal Engineering 87, 147-157.

doi.org/10.1016/j.coastaleng.2013.11.014 
4. De La Vega-Leinert, A.C. and S. Stoll-Kleemann (2015). Identifying gaps between science, policy and societal perspectives on coastal land use: The case of managed realignment in Darß - Zingst region, Mecklenburg Western Pomerania, Eastern German Baltic coast. In S. Stoll-Kleemann (ed.) Local Perceptions and Preferences for Landscape and Land Use in the Fischland-Darß-Zingst Region, German Baltic Sea, Greifswalder Geographische Arbeiten Bd. 51, Institut für Geographie und Geologie der ErnstMoritz-Arndt Universität Greifswald

5. Doody, J.P. (2008). Physical States, Restoration Methods. In J.P. Doody, Saltmarsh conservation, management and restoration Vol. 12 (pp. 90-107) Springer Science \& Business Media.

6. Eertman, R.H.M., B.A. Kornman, E. Stikvoort and H. Verbeek (2002). Restoration of the Sieperda Tidal Marsh in the Scheldt Estuary, The Netherlands. Restoration Ecology 10(3), 438-449. doi:10.1046/j.1526-100X.2002.01034.X

7. Esteves, L.S. (2014a). What is Managed Realignment? In L. S. Esteves (Ed.), Managed Realignment: A Viable Long-Term Coastal Management Strategy? (pp. 19-32). Dordrecht: Springer Netherlands.

8. Esteves, L.S. (2014b). Methods of Implementation. In L. S. Esteves (Ed.), Managed Realignment: A Viable Long-Term Coastal Management Strategy? (pp. 3345). Dordrecht: Springer Netherlands.

9. French, P.W. (2006). Managed realignment - the developing story of a comparatively new approach to soft engineering. Estuarine, Coastal and Shelf Science 67(3), 409-423. doi.org/10.1016/j.ecss.2005.11.035

10. Gedan, K., M.L. Kirwan, E. Wolanski, E. Barbier and B. Silliman (2011). The present and future role of coastal wetland vegetation in protecting shorelines: Answering recent challenges to the paradigm. Climatic Change 106(1), 7-29. doi:10.1007/s10584010-0003-7

11. Goeldner-Gianella, L. (2007). De-Polderizing in Western Europe: Overview of a new form of coastal management at the beginning of the twenty-first century. Annales de géographie, 656(4), 339-360. doi:10.3917/ag.656.0339.

12. Higuchi, T., T. Bruggemann, S. Obeahon, J. Gosden and A. Elder (2014). Medmerry Realignment Scheme: Design and Construction of an Earth Embankment on Soft Clay Foundation. From Sea to Shore - Meeting the Challenges of the Sea. January 2014, 888-897.

13. Hubrechts, J. and D. Defloor (2018). Project Hedwige-Prosper: creation of new wetlands along the river Scheldt. Dredging International.

14. Morris, R.K.A. (2013). Managed realignment as a tool for compensatory habitat Creation: A re-appraisal Ocean \& Coastal Management 73, 82-91. dx.doi.org/10.1016/j.ocecoaman.2012.12.013

15. Reed, D., B. van Wesenbeeck, P.M.J. Herman and E. Meselhe (2018). Tidal flat-wetland systems as flood defenses: Understanding biogeomorphic controls. Estuarine, Coastal and Shelf Science 213, 269-282. doi:10.1016/j.ecss.2018.08.017
16. Reitsma, J.M. and J. de Jong (2018). Toelichting bij de Vegetatiekartering Westerschelde 2016. In opdracht van Rijkswaterstaat WVL.

17. Rupp-Armstrong, S. and R.J. Nicholls (2007). Coastal and Estuarine Retreat: A Comparison of the Application of Managed Realignment in England and Germany. Journal of Coastal Research 2007(236), 1418-1430. doi.org/10.2112/04-0426.1

18. Schernewski, G., Bartel, C., Kobarg, N., \& Karnauskaite, D. (2018). Retrospective assessment of a managed coastal realignment and lagoon restoration measure: the Geltinger Birk, Germany. Journal of Coastal Conservation 22(1), 157-167. doi.org/10.1007/s11852-017-0496-6

19. Schuerch, M., T. Spencer, S. Temmerman, M.L. Kirwan, C. Wolff, D. Lincke, C. J. McOwen, M.D. Pickering, R. Reef, A.T. Vafeidis, J. Hinkel, R.J. Nicholls and S. Brown (2018). Future response of global coastal wetlands to sea-level rise. Nature 561, 231-234. doi.org/10.1038/s41586-018-0476-5

20. Shepard, C., C. Crain and M. Beck (2011). The protective role of coastal marshes: A systematic review and meta-analysis. Plos One 6(11), 27374. doi:10.1371/journal.pone.0027374

21. Spencer, T., M. Schuerch, R.J. Nicholls, J. Hinkel, D. Lincke, A.T. Vafeidis, R. Reef, L. McFadden and S. Brown (2016). Global coastal wetland change under sea-level rise and related stresses: The DIVA Wetland Change Model. Global and Planetary Change 139, 15-30. doi.org/10.1016/j.gloplacha.2015.12.018

22. Stark, J., Y. Plancke, S. Ides, P. Meire and S. Temmerman (2016). Coastal flood protection by a combined nature-based and engineering approach: Modeling the effects of marsh geometry and surrounding dikes. Estuarine, Coastal and Shelf Science 175, 34-45. doi:10.1016/j.ecss.2016.03.027

23. Temmerman, S., P. Meire, T.J. Bouma, P.M.J. Herman, T. Ysebaert and H.J. De Vriend (2013). Ecosystem-based coastal defence in the face of global change. Nature 504(7478), 79-83. doi.org/10.1038/nature12859

24. van den Hoven, K., C. Kroeze and J.M. van LoonSteensma (in prep). Realigned dikes in European managed realignment. Manuscript in preparation.

25. van der Ham, W. (2009). Hollandse polders. Amsterdam: Boom.

26. van Loon-Steensma, J.M. and M. Kok (2016). Risk reduction by combining nature values with flood protection? E3s Web of Conferences 7, 13003. doi.org/10.1051/e3sconf/20160713003

27. van Staveren, M.F., J.F. Warner, M. Shah Alam Khan (2017). Bringing in the tides. From closing down to opening up delta polders via Tidal River Management in the southwest delta of Bangladesh. Water Policy 19 (1): 147-164. doi.org/10.2166/wp.2016.029 